\title{
Use of the anterior-posterior chest diameter in CT: reduction in radiation dose?
}

\author{
E. E. van der Wall · J. D. Schuijf · J. J. Bax
}

Received: 20 May 2010/Accepted: 21 May 2010/Published online: 5 June 2010

(C) The Author(s) 2010. This article is published with open access at Springerlink.com

In recent years, computed tomography (CT) angiography has emerged as a reliable non-invasive method for the assessment of coronary artery disease, coronary anatomy and cardiac function [1-17]. Multiple studies involving over several thousands of patients have established that CT angiography is highly accurate for delineation of the presence and severity of coronary atherosclerosis [18-23]. CT angiography may also reveal the total plaque burden, i.e. both calcified and non-calcified components, for individual patients with coronary atherosclerosis [24-35]. With its high negative predictive value cardiac CT is best suited to the evaluation of patients with a low or intermediate risk of coronary disease, allowing the non-invasive exclusion of coronary disease at relatively low cost and risk [20, 36-47]. However, the appropriate radiation dose remains an important issue in cardiac CT. A too low radiation dose may result in a high level of image noise and therefore in nonevaluable images. Conversely, using higher radiation exposure levels may put the patient at unnecessary risk of radiation damage [48-56].

Editorial comment on the article of Rogalla et al. (doi: 10.1007/s10554-010-9630-3)

E. E. van der Wall $(\bowtie) \cdot$ J. D. Schuijf · J. J. Bax Department of Cardiology, Leiden University Medical Center, PO Box 9600, 2300 RC Leiden, The Netherlands e-mail: e.e.van_der_wall@lumc.nl
In the current issue of the International Journal of Cardiovascular Imaging, Rogalla et al. [57] compared tube current adaptation based on three body mass index categories versus the anterior-posterior chest diameter for radiation dose optimization in patients undergoing dynamic volume cardiac CT. The anterior-posterior chest diameter of the patient's chest was chosen as a means to individualize the required tube load in cardiac CT with the aim of reducing inter-individual variation in technical image quality. Two cardiac imaging centers participated in the study which comprised a total of 40 evaluable patients. Twenty patients underwent a prospectively triggered 320-slice single beat cardiac CT using the X-ray tube current (mA) manually adjusted to the patient's body mass index (group I). In 20 subsequent patients, the tube current was adapted according to the patient's anterior-posterior chest diameter (group II). All other parameters were kept constant. Image noise was defined as the standard deviation of attenuation values and measured using a region of interest in the descending aorta. Variation in image noise was statistically compared between both patient groups. Average and standard deviation of pixel noise were 29.1 and 14.8 Hounsfield Units in group I and 28.0 and 4.2 Hounsfield Units in group II. Interindividual variation of pixel noise was significantly lower in group II versus group I.

The authors concluded that tube current adaptation based on anterior-posterior chest diameter was superior to stepwise adaptation based on body mass index 
for optimizing radiation dose in dynamic volume cardiac CT. Therefore, this approach limits unnecessary radiation dose while ensuring diagnostic image quality in patients with diverse body habitus. The current study at least suggests that tube current adaptation to the patient's chest diameter is better suited for constant technical image quality than adaptation to the body mass index in three categories. Since individual variation of noise values are reduced with the anterior-posterior chest diameter technique, smaller patients receive less radiation dose whereas larger patients achieve improved image quality. The authors propose a simple method to account for variations in thoracic dimension between patients in order to predict the required tube settings for CT coronary angiography, thereby reducing inter-individual variation in image quality. This method ensures the lowest radiation dose for every individual, at the same time preserving adequate diagnostic image quality.

Currently, there are pressing questions about radiation safety of cardiac CT scans. The median exposure of CT angiography is roughly equivalent to 600 chest X-rays $(12 \mathrm{mSv})$. Traditional angiography exposes patients to roughly half the dose of CT angiography. However, the radiation exposure of almost 2,000 people having 64-slice cardiac CT images at 50 medical centers in different countries may vary more than sixfold [58]. Effective strategies to reduce radiation dose, such as prospective gating, ECGcorrelated modulation of the tube current, and tube voltage below $100 \mathrm{keV}$, are becoming more and more available. In a recent paper by Leschka et al. [59], it was shown that adjustment of the scan length of CT coronary angiography using the images from calcium scoring instead of the scout was associated with a $16 \%$ reduction in radiation dose of dual-source CT coronary angiography. In a large multicenter study of coronary CT angiography in patients with excellent heart rate control, Labounty et al. [60] reported that the use of minimal padding (i.e. additional surrounding X-ray beam on time), was associated with a substantial reduction in radiation dose together with preserved image interpretability. Nonetheless, heart imaging tests should be used cautiously to minimize patient exposure to ionizing radiation. Cardiac imaging studies exposing patients to ionizing radiation should be ordered only after thoughtful consideration of the potential benefits to the patient, thereby keeping in line with the established so-called 'appropriateness' criteria. In recent years, for all cardiac imaging modalities appropriateness criteria have been established with the primary aim to adhere to the primary indications. As to CT angiography, Ayyad et al. [61] showed that the number of appropriate CT examinations increased from 69.5 to $78.5 \%$ during the period from 2006 to 2007, whereas the number of inappropriate examinations decreased from 11.5 to $4.6 \%$. Interestingly, cardiologists were more likely than noncardiologists to order CT examinations that were appropriate during the study period. However, a more recent study by Miller et al. [62] suggested that still a significant proportion (46\%) of the coronary CT angiography studies are for indications not covered by the published appropriateness criteria. Adherence to the appropriateness criteria is of paramount importance in clinical practice. This policy will have a significant impact on physician decision making and patient care, such as exposure to a minimal radiation dose.

To summarize, the anterior-posterior chest diameter adapted tube current in dynamic volume CT coronary angiography, as proposed by Rogalla et al. [57], provides a new simple and practical approach to keep image quality constant by accounting for differences in patient size. Maintaining a constant image quality in CT, independent of patient body habitus, significantly contributes to a substantially improved diagnostic image quality together with a reduced radiation dose for the patient.

Open Access This article is distributed under the terms of the Creative Commons Attribution Noncommercial License which permits any noncommercial use, distribution, and reproduction in any medium, provided the original author(s) and source are credited.

\section{References}

1. Schuijf JD, Bax JJ, van der Wall EE (2007) Anatomical and functional imaging techniques: basically similar or fundamentally different? Neth Heart J 15:43-44

2. Juwana YB, Wirianta J, Suryapranata H, de Boer MJ (2007) Left main coronary artery stenosis undetected by 64-slice computed tomography: a word of caution. Neth Heart J 15:255-256

3. Wijpkema JS, Dorgelo J, Willems TP et al (2007) Discordance between anatomical and functional coronary stenosis severity. Neth Heart J 15:5-11

4. Bax JJ, Lamb H, Dibbets P, Pelikan H et al (2000) Comparison of gated single-photon emission computed 
tomography with magnetic resonance imaging for evaluation of left ventricular function in ischemic cardiomyopathy. Am J Cardiol 86:1299-1305

5. van der Wall EE, Heidendal GA, den Hollander W, Westera G, Roos JP (1980) I-123 labeled hexadecenoic acid in comparison with thallium-201 for myocardial imaging in coronary heart disease. A preliminary study. Eur J Nucl Med 5:401-405

6. Bavelaar-Croon CD, Pauwels EK, van der Wall EE (2001) Gated single-photon emission computed tomographic myocardial imaging: a new tool in clinical cardiology. Am Heart J 141:383-390

7. Molhoek SG, Bax JJ, Bleeker GB et al (2004) Comparison of response to cardiac resynchronization therapy in patients with sinus rhythm versus chronic atrial fibrillation. Am J Cardiol 94:1506-1509

8. Thygesen K, Alpert JS, White HD (2007) Universal definition of myocardial infarction; joint ESC/ACCF/AHA/ WHF task force for the redefinition of myocardial infarction. Eur Heart J 28:2525-2538

9. van Lennep JE, Westerveld HT, van Lennep HW, Zwinderman AH, Erkelens DW, van der Wall EE (2000) Apolipoprotein concentrations during treatment and recurrent coronary artery disease events. Arterioscler Thromb Vasc Biol 20:2408-2413

10. Bavelaar-Croon CD, Kayser HW, van der Wall EE et al (2000) Left ventricular function: correlation of quantitative gated SPECT and MR imaging over a wide range of values. Radiology 217:572-575

11. van der Wall EE, van Dijkman PR, de Roos A et al (1990) Diagnostic significance of gadolinium-DTPA (diethylenetriamine penta-acetic acid) enhanced magnetic resonance imaging in thrombolytic treatment for acute myocardial infarction: its potential in assessing reperfusion. Br Heart $\mathrm{J}$ 63:12-17

12. van Dijkman PR, van der Wall EE, de Roos A et al (1991) Acute, subacute, and chronic myocardial infarction: quantitative analysis of gadolinium-enhanced MR images. Radiology 180:147-151

13. van de Wal RM, van Werkum JW, le Cocq d'Armandville MC et al (2007) Giant aneurysm of an aortocoronary venous bypass graft compressing the right ventricle. Neth Heart J 15:252-254

14. de Leeuw JG, Wardeh A, Sramek A, van der Wall EE (2007) Pseudo-aortic dissection after primary PCI. Neth Heart J 15:265-266

15. Braun S, van der Wall EE, Emanuelsson S, Kobrin I (1996) Effects of a new calcium antagonist, mibefradil (Ro 405967), on silent ischemia in patients with stable chronic angina pectoris: a multicenter placebo-controlled study. The mibefradil international study group. J Am Coll Cardiol 27:317-322

16. ten Kate GJ, Wuestink AC, de Feyter PJ (2008) Coronary artery anomalies detected by MSCT-angiography in the adult. Neth Heart J 16:369-375

17. Schuijf JD, Jukema JW, van der Wall EE, Bax JJ (2007) Multi-slice computed tomography in the evaluation of patients with acute chest pain. Acute Card Care 9:214-221

18. Groen JM, Greuter MJ, Vliegenthart R et al (2008) Calcium scoring using 64-slice MDCT, dual source CT and
EBT: a comparative phantom study. Int $\mathrm{J}$ Cardiovasc Imaging 24:547-556

19. van Werkhoven JM, Schuijf JD, Jukema JW et al (2008) Anatomic correlates of a normal perfusion scan using 64-slice computed tomographic coronary angiography. Am J Cardiol 101:40-45

20. Bakx AL, van der Wall EE, Braun S, Emanuelsson H, Bruschke AV, Kobrin I (1995) Effects of the new calcium antagonist mibefradil (Ro 40-5967) on exercise duration in patients with chronic stable angina pectoris: a multicenter, placebo-controlled study. Ro 40-5967 International Study Group. Am Heart J 130:748-757

21. Schuijf JD, Pundziute G, Jukema JW et al (2006) Diagnostic accuracy of 64-slice multislice computed tomography in the noninvasive evaluation of significant coronary artery disease. Am J Cardiol 98:145-148

22. Jongbloed MR, Lamb HJ, Bax JJ et al (2005) Noninvasive visualization of the cardiac venous system using multislice computed tomography. J Am Coll Cardiol 45:749-753

23. Schuijf JD, Wijns W, Jukema JW et al (2006) Relationship between noninvasive coronary angiography with multislice computed tomography and myocardial perfusion imaging. J Am Coll Cardiol 48:2508-2514

24. Pundziute G, Schuijf JD, Jukema JW et al (2007) Prognostic value of multislice computed tomography coronary angiography in patients with known or suspected coronary artery disease. J Am Coll Cardiol 49:62-70

25. Henneman MM, Schuijf JD, Pundziute G et al (2008) Noninvasive evaluation with multislice computed tomography in suspected acute coronary syndrome: plaque morphology on multislice computed tomography versus coronary calcium score. J Am Coll Cardiol 52:216-222

26. de Nooijer R, Verkleij CJ, von der Thüsen JH et al (2006) Lesional overexpression of matrix metalloproteinase-9 promotes intraplaque hemorrhage in advanced lesions but not at earlier stages of atherogenesis. Arterioscler Thromb Vasc Biol 26:340-346

27. Hoogendoorn LI, Pattynama PM, Buis B, van der Geest RJ, van der Wall EE, de Roos A (1995) Noninvasive evaluation of aortocoronary bypass grafts with magnetic resonance flow mapping. Am J Cardiol 75:845-848

28. van der Laarse A, Kerkhof PL, Vermeer F et al (1988) Relation between infarct size and left ventricular performance assessed in patients with first acute myocardial infarction randomized to intracoronary thrombolytic therapy or to conventional treatment. Am J Cardiol 61:1-7

29. van der Wall EE, den Hollander W, Heidendal GA, Westera G, Majid PA, Roos JP (1981) Dynamic myocardial scintigraphy with 123I-labeled free fatty acids in patients with myocardial infarction. Eur $\mathrm{J}$ Nucl Med 6:383-389

30. Vliegen HW, Doornbos J, de Roos A, Jukema JW, Bekedam MA, van der Wall EE (1997) Value of fast gradient echo magnetic resonance angiography as an adjunct to coronary arteriography in detecting and confirming the course of clinically significant coronary artery anomalies. Am J Cardiol 79:773-776

31. van der Hoeven BL, Pires NM, Warda HM et al (2005) Drug-eluting stents: results, promises and problems. Int $\mathbf{J}$ Cardiol 99:9-17 
32. Ertaş G, van Beusekom HM, van der Giessen WJ (2009) Late stent thrombosis, endothelialisation and drug-eluting stents. Neth Heart J 17:177-180

33. Pluim BM, Lamb HJ, Kayser HW et al (1998) Functional and metabolic evaluation of the athlete's heart by magnetic resonance imaging and dobutamine stress magnetic resonance spectroscopy. Circulation 97:666-672

34. Scholte AJ, Schuijf JD, Kharagjitsingh AV et al (2008) Different manifestations of coronary artery disease by stress SPECT myocardial perfusion imaging, coronary calcium scoring, and multislice CT coronary angiography in asymptomatic patients with type 2 diabetes mellitus. J Nucl Cardiol 15:503-509

35. Scholte AJ, Schuijf JD, Kharagjitsingh AV et al (2008) Prevalence of coronary artery disease and plaque morphology assessed by multi-slice computed tomography coronary angiography and calcium scoring in asymptomatic patients with type 2 diabetes. Heart 94:290-295

36. Torn M, Bollen WL, van der Meer FJ, van der Wall EE, Rosendaal FR (2005) Risks of oral anticoagulant therapy with increasing age. Arch Intern Med 165:1527-1532

37. Ypenburg C, Schalij MJ, Bleeker GB et al (2007) Impact of viability and scar tissue on response to cardiac resynchronization therapy in ischaemic heart failure patients. Eur Heart J 28:33-41

38. Ypenburg C, Roes SD, Bleeker GB et al (2007) Effect of total scar burden on contrast-enhanced magnetic resonance imaging on response to cardiac resynchronization therapy. Am J Cardiol 99:657-660

39. de Roos A, Matheijssen NA, Doornbos J et al (1990) Myocardial infarct size after reperfusion therapy: assessment with Gd-DTPA-enhanced MR imaging. Radiology 176:517-521

40. de Roos A, Matheijssen NA, Doornbos J, van Dijkman PR, van Rugge PR, van der Wall EE (1991) Myocardial infarct sizing and assessment of reperfusion by magnetic resonance imaging: a review. Int $\mathbf{J}$ Card Imaging 7: 133-138

41. van Rugge FP, van der Wall EE, van Dijkman PR, Louwerenburg HW, de Roos A, Bruschke AV (1992) Usefulness of ultrafast magnetic resonance imaging in healed myocardial infarction. Am J Cardiol 70:1233-1237

42. Holman ER, van Jonbergen HP, van Dijkman PR, van der Laarse A, de Roos A, van der Wall EE (1993) Comparison of magnetic resonance imaging studies with enzymatic indexes of myocardial necrosis for quantification of myocardial infarct size. Am J Cardiol 71:1036-1040

43. Bleeker GB, Schalij MJ, Boersma E et al (2007) Relative merits of M-mode echocardiography and tissue Doppler imaging for prediction of response to cardiac resynchronization therapy in patients with heart failure secondary to ischemic or idiopathic dilated cardiomyopathy. Am J Cardiol 99:68-74

44. Ypenburg C, Sieders A, Bleeker GB et al (2007) Myocardial contractile reserve predicts improvement in left ventricular function after cardiac resynchronization therapy. Am Heart J 154:1160-1165

45. Ypenburg C, van der Wall EE, Schalij MJ, Bax JJ (2008) Imaging in cardiac resynchronisation therapy. Neth Heart $\mathbf{J}$ 16:S36-S40
46. Nemes A, Geleijnse ML, van Geuns RJ et al (2008) Dobutamine stress MRI versus threedimensional contrast echocardiography: it's all black and white. Neth Heart J 16:217-218

47. van der Geest RJ, Niezen RA, van der Wall EE, de Roos A, Reiber JH (1998) Automated measurement of volume flow in the ascending aorta using MR velocity maps: evaluation of inter- and intraobserver variability in healthy volunteers. J Comput Assist Tomogr 22:904-911

48. Tops LF, Schalij MJ, Holman ER, van Erven L, van der Wall EE, Bax JJ (2006) Right ventricular pacing can induce ventricular dyssynchrony in patients with atrial fibrillation after atrioventricular node ablation. J Am Coll Cardiol 48:1642-1648

49. Bleeker GB, Holman ER, Steendijk P et al (2006) Cardiac resynchronization therapy in patients with a narrow QRS complex. J Am Coll Cardiol 48:2243-2250

50. Bleeker GB, Bax JJ, Fung JW et al (2006) Clinical versus echocardiographic parameters to assess response to cardiac resynchronization therapy. Am J Cardiol 97:260-263

51. van Rugge FP, Boreel JJ, van der Wall EE et al (1991) Cardiac first-pass and myocardial perfusion in normal subjects assessed by sub-second Gd-DTPA enhanced MR imaging. J Comput Assist Tomogr 15:959-965

52. van der Wall EE, Vliegen HW, de Roos A, Bruschke AV (1995) Magnetic resonance imaging in coronary artery disease. Circulation 92:2723-2739

53. Oemrawsingh PV, Mintz GS, Schalij MJ, Zwinderman AH, Jukema JW, van der Wall EE (2003) Intravascular ultrasound guidance improves angiographic and clinical outcome of stent implantation for long coronary artery stenoses: final results of a randomized comparison with angiographic guidance (TULIP Study). Circulation 107:62-67

54. Portegies MC, Schmitt R, Kraaij CJ et al (1991) Lack of negative inotropic effects of the new calcium antagonist Ro 40-5967 in patients with stable angina pectoris. J Cardiovasc Pharmacol 18:746-751

55. Tops LF, Bax JJ, Zeppenfeld K et al (2005) Fusion of multislice computed tomography imaging with three-dimensional electroanatomic mapping to guide radiofrequency catheter ablation procedures. Heart Rhythm 2:1076-1081

56. Gerber TC, Kuzo RS, Morin R (2005) Techniques and parameters for estimating radiation exposure and dose in cardiac computed tomography. Int $\mathbf{J}$ Cardiovasc Imaging 21:165-176

57. Rogalla P, Blobel J, Kandel S et al. (2010) Radiation dose optimisation in dynamic volume CT of the heart: tube current adaptation based on anterior-posterior chest diameter. Int $\mathbf{J}$ Cardiovasc Imaging. [Epub ahead of print]

58. Hausleiter J, Meyer T, Hermann F et al (2009) Estimated radiation dose associated with cardiac $\mathrm{CT}$ angiography. JAMA 301:500-507

59. Leschka S, Kim CH, Baumueller S et al (2010) Scan length adjustment of CT coronary angiography using the calcium scoring scan: effect on radiation dose. AJR Am J Roentgenol 194:W272-W277

60. Labounty TM, Leipsic J, Min JK et al (2010) Effect of padding duration on radiation dose and image interpretation in prospectively ECG-triggered coronary CT angiography. AJR Am J Roentgenol 194:933-937 
61. Ayyad AE, Cole J, Syed A et al (2009) Temporal trends in utilization of cardiac computed tomography. J Cardiovasc Comput Tomogr 3:16-21
62. Miller JA, Raichlin E, Williamson EE et al (2010) Evaluation of coronary CTA Appropriateness Criteria in an academic medical center. J Am Coll Radiol 7:125-131 